\title{
The Understanding of Hadith on Jihad in LDII: A Study of Wali Barokah Kediri and Gading Mangu Jombang Pesantrens
}

\author{
Wahidul Anam \\ State Islamic Institute of Kediri \\ wahidulanam@yahoo.co.id
}

\begin{abstract}
Jihad is a term that continuously caught the attention of academics. The stigma of "radicalism" became a topic of discussion along with the emergence of various religious-based violence in Indonesia. The Indonesian Institute of Islamic Dawah (LDII) pesantrens (Islamic boarding schools) in Jombang and Kediri, East Java, are among large pesantrens in East Java, which have unique characteristics, including the study of the main books of hadith, Sabih al-Bukbari and Sabih Muslim. This article sheds light on their interpretation of hadith on jihad and its implication on the development of religious radicalism thoughts in LDII. It suggests that no indication of religious-based violence emerged in both LDII pesantrens. The students have been exposed to religious radicalism and have studied on jihad, but there have been almost no violent or radical movements in performing their religious duties. In addition, the students showed significant radical attitudes towards jihad. They agreed with jihad as written in the hadith books and ready to carry out jihad.
\end{abstract}

Keywords: Jihad, Radicalism, Islamic boarding school, LDII.

\begin{abstract}
Abstrak: Jihad merupakan satu istilah konseptual yang terus mendapat perhatian dari para akademisi. Stigma "radikalisme" menjadi topik perbincangan seiring dengan munculnya berbagai kekerasan berbasis agama di Indonesia. Pesantren Lembaga Dakwah Islam Indonesia (LDII) di Jombang dan Kediri, Jawa Timur, termasuk di antara pesantrenpesantren besar di Jawa Timur yang memiliki ciri khas, di antaranya adalah kajian terhadap kitab-kitab hadis otoritatif, yaitu Saḅị al-Bukhäri dan Sahị Muslim. Artikel ini menyoroti interpretasi mereka terhadap hadis tentang jihad dan implikasinya terhadap perkembangan pemikiran radikalisme agama di LDII. Tulisan ini menunjukkan bahwa tidak ada indikasi kekerasan berbasis agama yang muncul di kedua pesantren LDII tersebut. Para santri pada dasarnya telah bersinggungan dengan radikalisme agama dan juga telah mempelajari jihad, namun hampir tidak ditemukan adanya gerakan kekerasan atau radikal dalam menjalankan tugas keagamaannya. Meski demikian, di sisi lain para santri juga menunjukkan sikap radikal yang signifikan terhadap jihad. Hal itu tampak
\end{abstract}


dari sikap mereka yang sepakat dengan jihad seperti yang tertulis dalam kitab-kitab hadits dan mereka juga siap untuk melakukan jihad.

Kata kunci: Jihad, Radikalisme, Pesantren, LDII.

\section{Pendahuluan}

Jihad is a term that has been of concern to academics lately due to the emergence of religious radicalism movements around the world. The radical stigma has also become a topic of conversation along with the emergence of radical movements in the name of religion in Indonesia. After 9/11 bombing which targeted W'TC and Pentagon buildings in the United States (2001), jihad and radicalism have been discussed by academics, intellectuals, and people in general. The US authorities identified the actor of that incident as the radical Islamic group, al-Qaeda.

In Indonesia, the terms jihad and radicalism have become common terms and have become a daily conversation among various groups, especially academics. This occurs with the increasing frequency of radical action in various forms. According to research conducted by the Wahid Institute, in August 2017, 11 million people have been willing to take radical actions, $0.4 \%$ of Indonesian population has acted radically, and another $7.7 \%$ population was willing to act radically, if possible. These data indicate that radicalism in Indonesia is already at an alarming level.

The Ma'arif Institute (2017) research showed that radicalism movements in the name of religion have entered Senior High Schools (SMA). A survey conducted by the Jakarta Institute for Islamic Studies and Peace in 2010 was quite shocking: $48.9 \%$ of students in Greater Jakarta expressed their approval of radical action. Meanwhile, among university students, there was an increase in religious radicalism. Reports from the National Counter Terrorism Agency, many universities in Indonesia have exposed radicalism, including Indonesia University, Bandung Institute of Technology, IPB University, Diponegoro University, Sepuluh Nopember Institute of Technology, Airlangga University, Brawijaya University, and several Islamic Universities in Indonesia.

Interestingly, although many general schools have been exposed to religious radicalism, many Islamic boarding schools which teach religion do not show such strong religious radicalism. The Secretariat of the Directorate General of Islamic Education of the Ministry of Religion reported there were 28,194 Islamic boarding schools with 
4,290,626 students in 2016. National Counter Terrorism Agency said that there were only 19 Islamic boarding schools that indicated and have been exposed to religious radicalism. This percentage is small compared to the number of Islamic boarding schools that exist, even though this is a symptom or seed of religious radicalism that must be a concern to all people.

The LDII Islamic boarding schools in both Jombang and Kediri are among the large Islamic boarding schools in East Java that have different characteristics among the thousands of pesantrens in Indonesia. Of LDII Islamic boarding schools' interesting characteristics is the study of the main hadith books, i.e. Sabị alBukbari and Sabì Muslim. One of the exciting chapters to discuss is jihad, as it revealed the dynamic Islamic thought in recent decades. Students can be sure to have learned jihad directly from the Prophet Muhammad through the narrations they received from the hadith books they studied.

An interesting phenomenon is that the number of higher students and University students affected by religious radicalism has increased significantly, but the students who have studied 'jihad', do not engage in violent or radical movements in carrying out their religious activities. This article focuses on (1) how kiai (Islamic ulama) and students understand jihad and religious radicalism in the LDII Islamic boarding schools in both Jombang and Kediri (2) how much potential they have to carry out acts of religious radicalism, and (3) to what extent this potential will emerge after they study the concept of jihad in the hadith books.

\section{The History of LDII and Its Pesantrens}

LDII, as one of the official community organizations in Indonesia, can adapt to the changing concept of its strategic environment and obey the constitution of Indonesia. Externally, each organization is bound by the constitution of the state in which the organization is located. LDII is externally bound by the 1945 constitution and community Organization constitution no. 17 of 2013 which have been consolidated but not yet enacted. After the LDII organization received legalization from the state as a social and nonpolitical organization, LDII was required to build a self-image.

Pondok Pesantren Wali Barokah LDII Kediri under Wali Barokah Foundation was founded by KH. Nurhasan al-Ubaidah bin 
KH. Abdul Aziz who wanted to preach Islamic teachings based on the holy book al-Qur'an and hadith. ${ }^{1}$ The guidelines for the Wali Barokah Islamic Boarding School are based on the basic rights of religious freedom guaranteed by the 1945 Constitution. The da'wa of Islam must be in line with Indonesian framework as a continuation of the Indonesian nation's struggle to defend and fill independence and achieve the ideals of the Indonesian nation as stated in the Preamble of 1945 Constitution, namely protecting the entire Indonesian nation and all Indonesian blood, promote public welfare, educate the nation's life, and participate in implementing world order based on freedom, eternal peace and social justice. Participation from all levels of Indonesian society is required to achieve this goal. Enhancing religious life and participating in community development are important to create a just and prosperous society both materially and spiritually and with good morals.

In 1950, KH. Nurhasan Ubaidah went to Kediri Regency to preach in a mosque belonging to Damah, a rich man in Burengan Village, Pesantren District Kediri Regency. Initially, he held the Qur'an recitation attended by 25 people. Because of his patience and persistence, he gradually bought a new house on Jalan Kenari No. 9 which is located close to the Damah's small mosque (now known as Jalan Letjend. Suprapto gang I/21 Kediri) which became the forerunner of Islamic boarding schools in Burengan and Banjaran villages, Regency.

Two years later, KH. Nurhasan Ubaidah expanded his movement to a nearside of the city, exactly at Jombang. Totok Raharjo, the head of public relation division at pesantren Gading Mangu, reported that KH. Nurhasan Ubaidah founded PP. Gading Mangu in Perak District, Jombang in 1952. Due to the society's growing demand, several formal educational institutions were established in the pesantren in 1982, namely junior high school (SMP), senior high school (SMA), and vocational high school (SMK) Budi Utomo. The Budi Utomo Foundation has managed all formal educational institutions in PP Gading Mangu since 1996 to strengthen the pesantren. The pesantren separated regular santris who are studying at

\footnotetext{
${ }^{1}$ Focus Group Discussion with Suparjo, Zainal Muhith, and Abdur Rozaq at Wali Barokah dan Gading Mangu pesantrens on 21 July 2019.
} 
the pesantren only and students who attend the formal schools (SMP, SMA, and SMK Budi Utomo). ${ }^{2}$

Similar to the Wali Barokah Kediri pesantren, students of pesantren Gading Mangu study the Qur'an, focusing on the reading, translation, and interpretation, as well as hadith (including al-kutub alsittab), Islamic inheritance law (fara'id), Qira'at Sab'ab (seven variants of Qur'anic recitation), Nahw-Sarf (gramatical) and tahfir al-Qur'an (Qur'anic memorization). Both pesantrens taught al-kutub al-sittah (the six authoritative book of hadith) using the same model under the guidance of the teachers by translating the books textually and giving explanations. ${ }^{3}$ Statistically, there are about 6,565 santris (3215 male and 3350 female students) studying at pesantren Gading Mangu. ${ }^{4}$ The students came from various regions of Indonesia.

\section{Radicalism: Concept, Genealogy, and Impact}

Kartodirjo defined radicalism as a religious movement that completely overhauled a political and social order using physical, ideological, cultural, oral, or written violence. Kallen added that radicalism emerges due to strong interpreted doctrine or ideology and assumption, that other groups are defiant, and there is no truth outside the group. ${ }^{5}$ Radicalism is a state political ideology that desires significant reforms and changes to achieve progress or improvement. ${ }^{6}$ Religious radicalism, initially known only to scientists and intellectuals, has become a familiar term to wider communities due to the frequent emergence of acts of violence in the name of religion (religious radicalism).

Mahmudati (in Alhairi) stated that radicalism is a thought or attitude characterized by four things: (1) intolerance and disrespect toward others' opinions or beliefs, (2) fanaticism or self-righteous attitudes and blaming others, (3) exclusive attitude, being closed and

2 Interview with Totok Raharjo, the head of public relation division, pesantren Gading Mangu, on 21 July 2019.

3 Observation in pesantren Gading Mangu on 21 July 2019.

${ }^{4}$ Interview with Totok Raharjo, on 21 July 2019.

5 Robingatun, "Radikalisme Islam dan Ancaman Kebangsaan," Empirisma: Jurnal Pemikiran dan Kebudayaan Islam, Vol. 26 No. 1 (2017), 99-100.

6 Puis A. Partanto dan M. Dahlan Al Barry, Kamus Ilmiyah Populer (Surabaya: Arkola, 1994), 648. 
acting differently compared to others, and (4) revolutionary attitude, which is the tendency to use violence to achieve one's goals.

The radicalism movement in Nusantara is closely related to the Salafi movement initiated by Muhammad b. 'Abd al-Wahhāb in the Middle East (Wahabi movement). The Wahabi movement's primary goal is to purify Islamic teachings and revive the Prophet Muhammad's teachings, as practiced by the early generations of Muslims. In its subsequent developments, the Salafi movements touched not only the dimensions of purification of creeds and rituals but also the intellectual and political dimensions. ${ }^{8}$

The radicalism movement became widespread after the Indonesian independence, especially since Kartosuwirjo led Darul Islam (around 1950) until Suharto's presidency era. During Suharto's era, the military, through Ali Moertopo conducted special operation (Opsus) to muzzle Suharto's political opponents and the Intelligence Coordinating Agency (Badan Koordinasi Intelijen/Bakin), to discredit Islam, engineered former DI / TII members to carry out jihadist actions.' Besides, many acts of religious-based anarchism (by individuals and groups) in Indonesia have been committed in recent decades. Developing rapidly in post-New Order Indonesia, radicalism movement uses Islam's name to replace the democratic system from the West. ${ }^{10}$ The easiest target is school and university students due to their 'unstable' nature.

Information technology advances rapidly in the millennial era. Some people expand their network to build violent narratives through religious interpretations or even to cultivate hate and destruction to their own country. Local and international terrorist groups have utilized various online media massively to spread their teachings, which are entirely inconsistent with the moral messages in the Qur'an and the sunna. According to Brookings Institution, by 2015 the 'hijra' groups, including those organized by the ISIS to propagandize their

\footnotetext{
7 Alhairi, "Pendidikan Anti Radikalisme: Ikhtiar Memangkas Gerakan Radikal," Tarbawi: Jurnal Pendidikan Islam, Vol. 14. No. 2 (2017), 112.

8 Edi Susanto, "Kemungkinan Munculnya Paham Islam Radikal di "Pondok Pesantren"," Tadrîs: Jurnal Pendidikan Islam. Vol. 2, No. 1, (2007), 7-8.

9 Robingatun, "Radikalisme Islam," 100.

10 Ali Syahidin Mubarok, "Mewujudkan Penafsir Otoritatif: Optimalisasi Tafsir Nusantara Sebagai Upaya Reduksi Gerakan Radikal," Qof: Jurnal Studi Al-Qur'an dan Tafsir, Vol. 2. No. 2 (2018), 180.
} 
teachings through the internet, had reached at least 46,000 Twitter accounts. ${ }^{11}$

Indonesia has suffered from radicalist and terrorist acts ${ }^{12}$ in the name of Islam, for example in the bombings of Kuta Bali, the Ahmadiyah case in Cekuesik Banten, the destruction of a church in Temanggung, and other acts of intolerance towards religion and country.

Other main causes of the emergence of radical movements include poor religious understanding, lack of knowledge on fiqh, and partial interpretation of religious texts. ${ }^{13}$ Many perpetrators of radical movements have been driven by lust. They argued that their actions relied on the Qur'an and sunna. ${ }^{14}$ They understand religious texts partially, not comprehensively; they learn religious knowledge (tafaqquh $\overline{f i}$ al-din) and moral messages in Islam (al-Qur'an, Hadith, ijmā' and qiyass) shallowly.

Al-Qaraḍāîi, citing al-Shătịibi, stated:

"Disputes that divide the Muslims into ummah or groups which are hostile to each other was caused by some Muslims' assumption about themselves; they considered themselves as mujtabid (Muslim jurist qualified to exercise ijtibäd in interpreting and evaluating Islamic law) while in fact they have not yet reached the degree. They act according to the Qur'anic interpretation that they understand and require others to follow them.... They make conclusions without understanding the meaning." 15

Many religious leaders in Indonesia ${ }^{16}$ have high hopes on religious moderation and are also obliged to disseminate the religious

11 Khairul Anam, "Radikalisme di Dunia Maya: Menemukan Tuhan di Mesin Pencarian," Empirisma: Jurnal Pemikiran dan Kebudayaan Islam, Vol. 26 No. 1 (2017), 3. 12 See also Riza Sihbudi, "Membaca Kemungkinan Kemerdekaan Negara Palestina," Al-Huda: Jurnal Kajian Ilmu-Ilmu Islam, Vol. 2, No. 5 (2002), 98.

13 Yusuf Qaradhawi, Membedah Islam Ekstrim, Terj: Alwi A.M (Bandung: Mizan, 2001), 53.

14 Alwi Shihab, Islam Inklusif: Menuju Sikap Terbuka Dalam Beragama (Bandung: Mizan, 1999), 147.

15 Qaradhawi, Membedah Islam, 53.

16 Indonesian Ministry of Religion has published a book on religious moderation in 2019 discussing a common ground for inter-religious communities and a means of da'wa through three things: conceptual study of religious moderation, empirical experience of religious moderation, and strategies for strengthening and implementing religious moderation. Kementerian Agama, Moderasi Beragama (Jakarta: Badan Litbang dan Diklat Kementerian Agama RI, 2009). 
moderation concepts and to prevent religious interpretation oriented to radicalism. ${ }^{17}$ For example, Sayyid Agil Husin al-Munawwar stated that non-Muslim leaders' issue may lead to racism and harsh words, blasphemy, and claiming others as munafiq and infidels. Said Agil Siraj, the chairman of the PBNU, said that Wali Songo's preachings are clear examples that Islamic da'wa may not relate to radical movements. Wali Songo made many contributions (sadaqah jariya; continuous charity) for the benefit of Indonesian ummah (community) and their da'wa model can be used as an uswah (example) in preaching in the present era.

\section{Understanding Jihad in the Hadith \\ 1. Meaning and Types of Jihad}

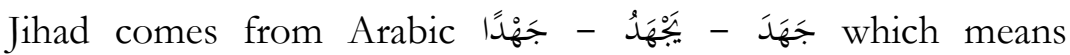
strength and striving to work hard. The term etymologically means putting all efforts and abilities to achieve a tough task, and the person who does jihad is called a mujahid. Grammatically, jihad is an ism

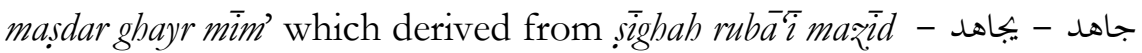
and universally means to work wholeheartedly, spiritually, physically and materially to seek the Divine pleasure. ${ }^{18}$

Jihad terminologically refers to directing all potentials in fending off an enemy's attack. Jihad has a broad meaning in Islamic law, including all forms of maximal effort in applying Islamic teachings and eradicating evil and injustice, both against oneself and society. AlShafi $\bar{c}_{\bar{i}}$ suggested that jihad is fighting the infidels to uphold Islam. ${ }^{19}$ However, people often misinterpret jihad in a narrow sense which has a strong and radical connotation.

Quoting Abū Darda', al-Ghazāili stated in his Ibya a' Ulumiddìn: "One who argues that getting ready in the morning (or at every opportunity) to study is not a jihad is really lacking argumentation and reason." Zayn al-Dīn al-Malibāri defined jihad as teaching religious

\footnotetext{
17 Shihab, Islam Inklusif, 149.

18 Ahzami Sami'un Jazuli, Fiqh al-Qur'an: Kajian atas Tema-Tema Penting dalam al-Quran (Jakarta: Kilau Intan, 2005), 42.

19 M. Saleh Mathar, "Jihad dan Terorisme Kajian Fikih Kontemporer," Hunafa: Jurnal Studia Islamika, Vol. 6, No.1 (2009), 119.
} 
sciences, solving problems in society, paying doctors, paying employees' salaries, etc. ${ }^{20}$

In the current era, defining jihad as fighting is against Islam's basic principles that uphold the values of peace, salvation, and antiradicalism. Jihad can be carried out in many capacities: sometimes carried out with the heart (e.g., by a serious intention to carry out Islamic da'wa), sometimes by enforcing bujjah (proof distinguishing truth from falsehood) against followers of evil and ideological heretics using strategies and arguments from the Qur'an, hadith, ijm $\bar{a}$, and qiyas, or against oneself. Thus, jihad is an obligation for every Muslim, depending on their respective capacities.

There are some types of jihad as it was popularly classified by some Muslim scholars:

a) Jihäd al-Nafs

Jihad against one's lust consists of four stages: (1) fighting lust by studying religious knowledge correctly, (2) jihad against one's lust by applying the knowledge learned, (3) jihad against one's lust by inviting people to learn and teach people who do not know, and (4) jihad against one's lust by enduring difficulties in the da'wa.

b) Jibäd al-Shaytān

Jihad against Satan consists of two levels: (1) jihad by rejecting Satan's preaching (such as doubt) and destructive temptation. Allah stated in Surah Fatir verse 6:

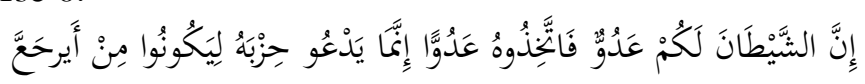

"Verily Satan is an enemy to you: Then treat him as an enemy. He only invites his adherents, that they may become Companions of the Blazing Fire."

c) Jihäd al-Kuffär wa al-Munäfiqin

Jihad against unbelievers and hypocrites has four levels: fighting with heart, verbally (mouth), wealth, and soul. Allah stated in Surah alTawbah verse 73 and Surat al-Tahrim verse 9:

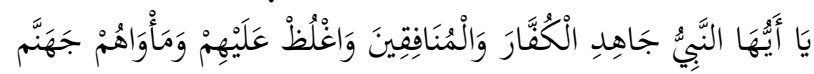

20 Zayn al-Dīn b. 'Abd al-'Azīiz al-Malibāri, Fatḥ al-Mu'īn (Surabaya: Nur al-Huda, tt), 133.

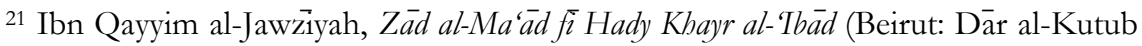
al-'Arabi, 2005), 415. 
"O Prophet! Strive hard against the disbelievers and the hypocrites, and be unyielding to them. Moreover, their abode is Hell, and evil is the destination."

d) Jihäd Arbāb al-Zulm wa al-Bida' wa al-Munkarät

The fourth type of jihad is jihad against tyranny, heresy, and wrongfulness. As stated by Prophet Muhammad:

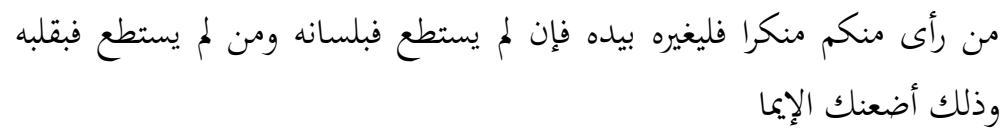

"Whosoever of you sees an evil action, let him change it with his hand; and if he is not able to do so, then with his tongue; and if he is not able to do so, then with his heart—and that is the weakest of faith."

\section{Hadiths on Jihad}

Some words stated by Prophet Muhammad have been used as an ideological basis for the religious obligation of jihad, in particular words which guaranteed that mujahids get noble degrees.

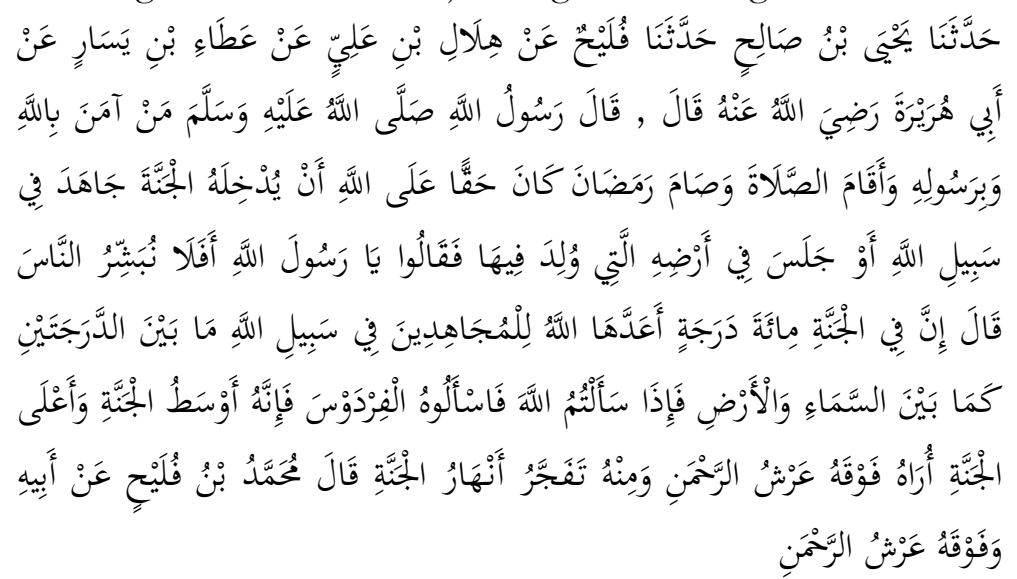

"Yahyyā b. Șălih had narrated to us from Fulayh from Hilāl b. 'Ali from 'Ața' b. Yassār from Abū Hurayrah who said: The Prophet said, "Whoever believes in Allah and His Apostle, doing prayer perfectly and fasting in the month of Ramadan, will rightfully be granted Paradise by Allah, no matter whether he/she fights in Allah or remains sitting on the land where he is born." The people said, "O the Apostle! Shall we acquaint the people with this?" He said, "Paradise has one-hundred grades which Allah has reserved for the Mujabidin who fight in His Cause, and the distance 
between each of two grades is like the distance between the Heaven and the Earth. So, when you ask Allah (for something), ask for al-Firdaws, which is the best and highest part of Paradise." Muhammad b. Fulayh's father added, "I think the Prophet also said, 'Above it (i.e. al-Firdaws) is the Throne of Beneficent (i.e. Allah), and from it originate the rivers of Paradise."'22

The prophet PBUH also stated in another hadith regarding rewards for people who engage in jihad.

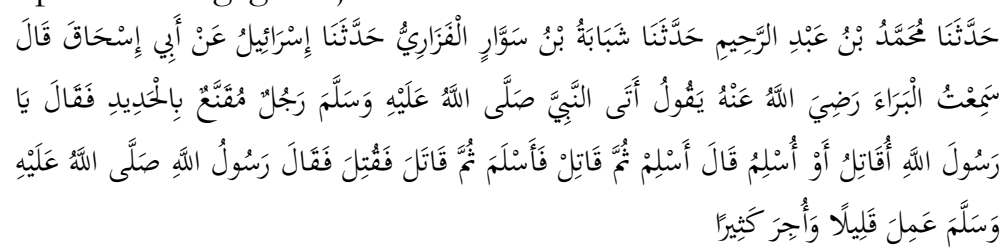

"Muhammad b. 'Abd al-Raḥim has told us from Shabābah b. Sawwar al-Fazarì from Isrā̄ill from Abū Isḥāq from al-Barā' (May Allah be pleased with him) reported: A man equipped with arms came to the Prophet and asked: "O Messenger of Allah! Should I go and fight or should I embrace Islam first?" He replied, "Enter in the fold of Islam and then fight." He embraced Islam and fought until he was killed. Thereupon the Messenger of Allah said, "He accepted Islam for a short time but was rewarded much."23

\section{Data Analysis and Data Description}

\section{a. Quantitative Data Description}

\section{Respondents' characteristics}

The data collection used in this study were qualitative and quantitative methods. The researchers surveyed 192 female $(62 \%)$ and 72 male (38\%) santris (students) residing in Pesantren Wali Barokah, Kediri, and Pesantren Gading Mangu, Jombang. The respondents were grouped into $12-16$-year-olds $(\mathrm{n}=27 ; 14 \%), 17-24$-year-olds $(\mathrm{n}=132 ; 69 \%)$, and $\geq 24$ year-olds $(\mathrm{n}=33 ; 17 \%)$.

To collect qualitative data, the researchers interviewed the caregivers and teachers who taught hadith at Wali Barokah and Gading Mangu pesantrens. In addition, the researchers also conducted direct field observations in both pesantrens.

\footnotetext{
${ }^{22}$ Muhammad b. Ismāīil b. al-Mughirah al-Bukhāri, Saḥị al-Bukhāri, 'Kitāb al-Jihād Bāb Darajāt al-Mujāhidin’ (Beirut: Dār al-Fikr, 2006).

${ }^{23}$ Ibid., 'Kitāb al-Jihād Bāb 'Amal al-Ṣaliḥ qabl al-Qitāl.'
} 


\section{Aspects of Tolerance with Other Religions}

There were 12 questions that the respondents answered. The data showed that the average respondents were very tolerant of other religions. When respondents were asked about whether religious differences were normal in people's lives, most respondents $(53.6 \%)$ agreed; $45.8 \%$ answered strongly agreed; and $0.5 \%$ chose to answer neutral. Similarly, when asked if good believers did not commit violence against other religious believers, all respondents agreed and some even strongly agreed. All respondents also rejected radical activities based on Prophet Muhammad's hadith. However, the respondent reacted very harshly when the issue of Shia and Ahmadiyya was presented. When asked if Shia and Ahmadiyya were heretical and were not part of Islam, 57.8\% agreed; $41.7 \%$ stated strongly disagree; only $0.5 \%$ of respondents said they were neutral. The findings showed that the respondents have great respect for other religions and have a high sense of tolerance, but they strongly disagreed and rejected the prophet's teachings on Muslim minority groups. The respondents radically reject Shia and Ahmadiyya.

The problem regarding worship site in LDII is also an interesting. When asked if followers of other religions could build places of worship in the respondent's environment, the respondents' answers varied: $68.8 \%$ of respondents answered that they agreed, as much as $21.9 \%$ of respondents said they had no attitude or neutrality. A total of $9.4 \%$ of respondents strongly agree answered.

Another sensitive issue was visiting other religions' worship places. $42.2 \%$ agreed to visit other religions' worship place; $34.9 \%$ of respondents chose to be neutral; and $6.8 \%$ strongly agree to such visit. On the other hand, $16.1 \%$ of respondents disagreed and refused to visit other religions' worship places. Thus, the study showed that although the respondents respect other religions, almost half of them disagreed with visiting other religion's worship places.

\section{Equality with Other Religions}

12 questions were related to equality with other religions. In general, respondents acknowledged that respecting other religions is an obligation. Respondents guaranteed the freedom of followers of other religions to worship according to their respective beliefs because embracing religion is part of human rights. Respondents also 
emphasized that worshipping in accordance with ones' respective religions is part of human rights. Respondents gave an agreed and strongly agreed to assessment.

However, the respondents have different opinions on spreading the religion to people who embraced another religion. 36.5\% agreed and $13 \%$ strongly agreed that spreading the religion to people who embrace another religion is permissible, and $29.7 \%$ chose to be neutral. On the other hand, as many as $2.1 \%$ of respondents strongly disagree and $18.8 \%$ of them disagree with the statement. Although embracing different religions is a human right, these respondents argued that preaching people who had embraced religion with another religion is unacceptable.

Regarding attitudes towards religious minorities, most respondents disagreed with discrimination against the minorities, although $15.1 \%$ of respondents gave a neutral answer, and $2.1 \%$ of respondents stated that the religious minorities have to yield to the majority. Likewise, regarding the statement of willingness to allow religious activities conducted by other religious followers, the majority of respondents gave a neutral response or agreement (47.9\%). A total of $2.6 \%$ of respondents strongly agree, and another $1 \%$ of respondents strongly disagree. Generally, these findings indicated that the respondents still had psychological concerns in interacting with the minorities.

The respondents' responses to the statements regarding their willingness to protect other religious believers and remind friends who insult other religions also varied. Neutral responses might mean potentials to not protecting other religious believers and insufficient willingness to reprimand friends insulting other religions.

\section{Cooperation with other religious believers}

Inter-religious cooperation is one of the pillars of multi-cultural and multi-religion life. The researchers analyzed how respondents cooperated with other religious believers after they learn hadiths about jihad. Most narrations were responded with 'agree' or 'very agree', including willingness to make a dialogue with other religious believers in non-religious topics, willingness to invite other believers to personal agenda (such as party and celebration), and willingness to cooperate with other believers in work-related.

However, the respondents' responses on sensitive issues varied. 34.9 respondents gave a neutral answer to a statement asking their 
willingness to attend non-Muslim's invitation, which might show a probability of disagreement. Also, although most respondents agreed or very agreed to give charity to non-Muslims in need, about $6.3 \%$ of respondents answered with a neutral.

\section{Jihad}

Jihad is one of basic principles of Islam which is very interesting to study. The term jihad is always related to the word religious radicalism. This is natural; terrorists who are involved in violence under the guise of religion always perceive to the public that they are jihad to defend religion. All respondents in this study have read the prophet's hadith which discusses the importance of jihad. When respondents responded to the narrative that when Islam was insulted by other people who are not of their religion, the respondents agreed and strongly agreed to carry out jihad, the number was very significant, $92.7 \%$. This shows that the issue of jihad is compassionate among the santris and administrators at LDII Pesantrens. Respondents are even ready to fight in the path of Allah with their souls and assets, only $0.5 \%$ of respondents reject this narrative. This means that Wali Barokah and Pondok Gading Mangu santris' desires for jihad were high.

Respondents also have the desire to be martyred, as all of them agreed or strongly agreed that being martyred in the way of Allah is the dream of every devout Muslim. The respondents had strong desires to defend their religion if their absolutely true religious values were disturbed.

However, all respondents disagreed with using violence in jihad, such as suicide bombing, and physical jihad. Most respondents considered violent jihad, such as in Suriah, was a wrong understanding of jihad. A few respondents $(0.5 \%)$ agreed with jihad using violence and another $1 \%$ of respondents expressed their neutrality.

The respondents gave different responses towards various jihad discourses and news in social media and internet. Almost half of respondents $(49.5 \%)$ stated that they were neutral, while $49 \%$ of respondents disagreed, and $1.6 \%$ strongly disagreed with the discourse and news of jihad in the internet. Respondents with neutral responses may agree or disagree with the discourse of jihad in social media and the internet. 
Regarding the best form of jihad, respondents stated that fighting against one's lust was the most ultimate form of jihad. The respondents preferred peaceful jihad and they disagreed with waging jihad using violence. Moreover, they stated that Pancasila and 1946 Constitution were final and did not contradict Islam. Thus, it could be concluded that the jihad discourse developed in Wali Barokah and Gading Mangu pesantrens remained within Indonesian framework.

\section{b. Qualitative Data}

\section{Concept of Jihad}

Pesantren circles were very familiar with the term jihad. Most fiqh and hadith books studied in pesantren discussed jihad. For example, the chapter of 'Kitāb al-Jihād' in Sahịị al-Bukbäri contains 203 sub-chapters, which indicates that jihad is an important concept in Islam. However, discussing jihad in non-Islamic and multi-religious countries in the contemporary era is a challenging topic. Some Muslims conceptualize jihad using a diversity framework, so jihad is humanistic. On the other hand, some Muslims conceptualized Islam radically and interpreted jihad textually as physical jihad, in which Muslims are willing to sacrifice their lives and souls to defend their beliefs if they thought that Islam was being insulted.

LDII santris and caretakers of Wali Barokah and Gading Mangu pesantren studied hadiths from the canons such as Sabị al-Bukbari,

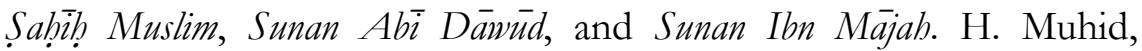
pesantren secretary and caretaker, suggested that jihad must be defined in Indonesian context. He added that one becomes a mujähid not by sacrificing him/herself and harming others, but by trying his/her utmost to spread Islam with his/her all belongings peacefully in his/her plural community and by respecting differences in the society. ${ }^{24}$

Another respondent, Sunarto, also echoed the idea of peaceful jihad. Sunarto suggested that the discussion of jihad in hadith books must be understood in a diverse framework. Further, H. Sunarto explained that Indonesia is a country with diverse religion, beliefs, cultures, languages, and customs. Redefining jihad in a humanistic manner is needed to keep peace and diversity. Jihad in a peaceful country and diversity era should be performed in a peaceful manner.

${ }^{24}$ Interview with Zainal Muhid at Wali Barokah pesantren on 21 July 2019. 
Physical jihad taught within the jihadist group only causes deaths for nothing. Sunarto also stated that recently emerged religious radicalism is jihadist's fatal error in interpreting jihad. He disagreed with religious radicalism movements because they are not Islamic teachings. ${ }^{25} \mathrm{Jihad}$ must be carried out peacefully.

Totok Raharjo, an administrator and Public Relation of LDII Gading Mangu pesantren, also rejected religious radicalism movements. Raharjo suggested that jihad as mentioned in canonical hadith books must be interpreted in the context of multi-cultural Indonesia. ${ }^{26} \mathrm{He}$ added that Indonesia and Islam are two things that should not be contested. Islamic values have been clearly reflected in Pancasila, so LDII members must not contrast state (Indonesia) and religion (Islam). LDII members must maintain a peaceful life even though there are some hadiths which permits violence in performing religious teachings and may be difficult to implement in a pluralistic society. For example:

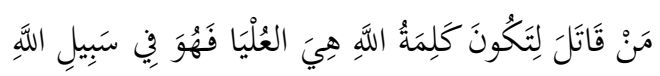

Literally, the hadith motivates Muslims to fight to raise Allah's sentences (religion) and informs that a Muslim who fights for Allah is in Allah's manner (sabililläh). according to Abdur Rozaq, ${ }^{27}$ a hadith teacher in pesantren Gading Mangu, the hadith is difficult to implement in a multi-cultural society. Therefore, the hadith is only taught without further explanation.

\section{Jihad within Indonesian Framework}

LDII has established itself as a da'wa organization within the Indonesian framework since its beginning. Ustadh Erianto, ${ }^{28}$ an LDII figure and teacher of Wali Barokah pesantren, stated that LDII is a da'wa organization and it commits to protect Indonesia. Article 5 of the third section of LDII Statutes and Bylaws (AD/ART) concerning the Principles, Purpose and Objectives of LDII emphasizes that LDII is based on Pancasila. Article 6 states that LDII was established to

\footnotetext{
25 Interview with Sunarto, Caretaker of Wali Barokah pesantren on 21 July 2019.

${ }^{26}$ Interview with Totok Raharjao, public relation of Gading Mangu pesantren on 21 July 2019.

27 Interview with Abdur Rozaq, a Hadith teacher at Gading Mangu pesantren on 4 August 2019

28 Interview with Erianto, one of caretakers of Wali Barokah pesantren on 3 November 2019.
} 
gather all potentials who have the same ideals, insights, and goals nationally, to form uniformed vision and perception in mobilizing national unity and oneness within Indonesian framework based on Pancasila and the 1945 Constitution. ${ }^{29}$

Wali Barokah and Gading Mangu pesantrens do not have a specific conceptual methodology in translating jihad-related hadiths. However, teachers explained the Qur'an and the prophet's hadiths by referring to classical scholars' opinions. For example, LDII teachers refer to Jalāl al-Dīn al-Suyựti and Jalāl al-Dīn al-Mahalli's and Ibn Kathir's tafsir books to interpret the Qur'an. Also, the teachers refer to codified canonical hadith books, such as Șạih al-Bukhäri and Sahih Muslim, as well as their sharb (explanation and interpretation) books, such as Fath al-Bäri and Sharh Sahịh Muslim by al-Nawawi in interpreting hadiths. ${ }^{30}$ Thus, the interpretation method used by LDII in understanding the prophet's hadiths is quite similar with other Muslim groups.

LDII pesantren caregivers understand that literal interpretation of hadiths may have a serious impact. For example, a hadith about people who have never fought are categorized as munafiq (hypocrite).

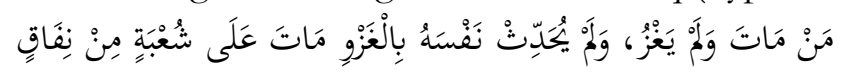

Textually, this hadith encourages Muslims to wage war. A mistake in interpreting the hadith can lead radical actions among LDII members. Similarly, the following hadith,

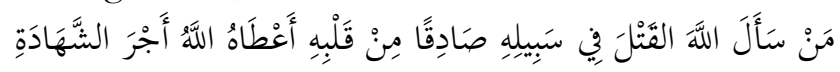

It explains that Allah will reward a person who sincerely desires to die in Allah's way with a shabid (martyrdom). When interpreted literally, the hadith motivates Muslims to die in the way of Allah to be a shahid.

Ustadh Eriono firmly stated that the above hadiths must be interpreted contextually and in line with LDII principles, namely Pancasila and 1945 Constitution. Ustadh Eriono added that all LDII teachers and members must adhere to Indonesian rules. These rules

29 AD/ART LDII, results of Keputusan Musyawarah Nasional VII Lembaga Dakwah Islam Indonesia Nomor: Kep-06/Munas VII LDII/Iii/2011 Tentang Perubahan AD/ART Lembaga Dakwah Islam Indonesia.

30 Interview with Erianto, caretaker of Wali Barokah pesantren on 3 November 2019 at Wali Barokah pesantren. 
can only be changed constitutionally in accordance with the state's legal basis.

H. Sunarto, chairman and caretaker of Wali Barokah pesantren, added that Indonesia is a republic state and not an Islamic one. Thus, interpretation of hadiths about jihad must be contextualized according to Indonesian regulations and laws. He added that LDII members are obliged to maintain unity and oneness in diversity. ${ }^{31}$ Ustadh Zunit Saifullah, the secretary of Majlis Taujih wal Irsyad, stated that the interpretation the hadiths contained in the jihad book compiled by Majlis Taujih wal Irsyad $^{32}$ must be adjusted to the Indonesian context because Indonesia is a pluralistic country, consisting of various tribes, religions, and races. LDII members are expected to be radical, that is, being serious but peaceful, in preaching LDII, so that Islam can develop well in Indonesia.

\section{Implementation of Islamic Sharia in Religious Pluralism}

The formalization of Islamic law is an important issue in Indonesian context. The establishment of various sharia financial services is a clear manifestation that Indonesian Muslim community is not against the formalization of sharia. Likewise, the discourse of sharia-based Indonesia put forward by Habib Riziq some time ago is continuously discussed despite pros and cons.

The interview data of LDII figures indicated that they agreed with the formalization of sharia provided that it is still within the framework of Pancasila and 1945 Constitution. Ustadh Erianto mentioned that the formalization of sharia is a positive effort in preaching Islam to the community. However, Islamic law does not have to be formalized if it is against the framework of Pancasila and the 1945 Constitution. He exemplified that LDII members can implement Islam well and carry out Islamic teachings peacefully and quietly without formalizing them.

\section{Conclusions}

The issue of the formalization of Islamic law is an important issue in the context of indifference. The establishment of various sharia financial services is a clear manifestation that the Indonesian

\footnotetext{
${ }^{31}$ Interview with H. Sunarto, chief and caretaker of Wali Barokah pesantren on 24 October 2019 in Wali Barokah pesantren.

32 Interview with Zunit Saifullah, Secretary of Majlis Taujih wal Irsyad, tanggal 6 October 2019 in Wali Barokah pesantren.
} 
Islamic community is not against the formalization of sharia. Likewise, the Republic of Indonesia's discourse with a law that was put forward by Habib Riziq some time ago, although there are pros and cons, it seems that the discourse is also continuing to develop. Based on interviews with several LDII figures, they agreed with the formalization of sharia, but still within the framework of Pancasila and the 1945 Constitution. According to Ustadh Erianto, the formalization of sharia is a positive effort in preaching Islam to the community, but he added that the implementation of Islamic law does not have to be formalized. He explained that although Islamic law has not been formalized, LDII members can still implement Islamic law well and carry out Islamic teachings such as performing daily prayers and other worships peacefully.

The results of the current study indicate that 1) All students of the Wali Barokah and Gading Mangu LDII pesantrens directly learn

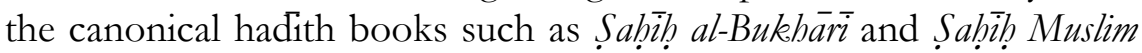
with their teachers. 2) LDII santris also studied Kitab al-jibad composed by Majlis Taujih wal Irsyad, which contains verses of the Qur'an and the prophet's hadiths about jihad. The book contains the sanad, matn, and the source of the hadiths, although it does not contain sharb (explanation) or description of the purpose of the hadith. 3) LDII figures interpreted jihad contextually according to Indonesian situation, although they use a common and general methodology of interpretation. 4) LDII figures interpret radicalism in da'wa as an effort to preach Islam seriously in society. Every santri is required to preach Islam to the community for certain time. Similarly, LDII members in the society have an obligation to preach Islam following LDII's vision. 5) Living in a multi-religious society, the board members, santris, and teachers of Wali Barokah and Gading Mangu pesantrens really respect and show high tolerance towards other religious believers, except towards followers of Ahmadiyyah and Shia which they considered as deviant cults.

\section{Bibliography}

AD/ART LDII. Hasil Keputusan Musyawarah Nasional VII Lembaga Dakwah Islam Indonesia Nomor: Kep-06/Munas VII LDII/Iii/2011 Tentang Perubahan Anggaran Dasar Dan Anggaran Rumah Tangga Lembaga Dakwah Islam Indonesia. 
Alhairi. "Pendidikan Anti Radikalisme: Ikhtiar Memangkas Gerakan Radikal." Tarbawi: Jurnal Pendidikan Islam, Vol. 14. No. 2 (2017).

Anam, Khairul. "Radikalisme di Dunia Maya: Menemukan Tuhan di Mesin Pencarian." Empirisma: Jurnal Pemikiran dan Kebudayaan Islam, Vol 26, No 1 (2017).

Asrori, Ahmad. "Radikalisme di Indonesia: Antara Historisitas dan Antropisitas." Kalam: Jurnal Studi Agama dan Pemikiran Islam, Vol. 9, No 2 (2015).

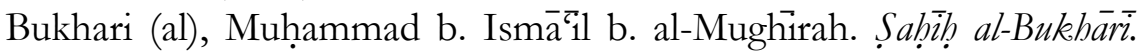
Beirut-Libanon: Dar al-Fikr, 2006.

Ghazāili (al), Abū Ḥāmid Muhammad b. Muhammad. Ihyà' 'Ulüm alDìn. Beirut: Dār al-Kutub al-'Ilmiyah, 2004.

Jawziyah (al), Ibn Qayyim. Zäd al-Ma'ád $\bar{f}$ Hady Khayr al-Tbād. Beirut: Dār al-Kutub al-'Arabi, 2005.

Jazuli, Ahzami Sami'un. Fiqh al-Qur'an: Kajian atas Tema-Tema Penting dalam al-Quran. Jakarta: Kilau Intan, 2005.

Kamarudin. "Jihad Dalam Perspektif Hadis." Hunafa: Jurnal Studia Islamika, Vol. 5, No. 1 (2008).

Kementerian Agama. Moderasi Beragama. Jakarta: Badan Litbang dan Diklat Kementerian Agama RI, 2009.

Malibāri (al), Zayn al-Dīn b. 'Abd al-'Aziz. Fath al-Muīn. Surabaya: Nur al-Huda, 2011.

Mathar, M. Saleh. "Jihad dan Terorisme Kajian Fikih Kontemporer," Hunafa: Jurnal Studia Islamika, Vol. 6, No. 1 (2009).

Mubarok, Ali Syahidin. "Mewujudkan Penafsir Otoritatif (Optimalisasi Tafsir Nusantara Sebagai Upaya Reduksi Gerakan Radikal)." Qof: Jurnal Studi Al-Qur'an dan Tafsir, Vol. 2, No. 2 (2018).

Partanto, Puis A. dan Al Barry, M. Dahlan. 1994. Kamus Ilmiyah Populer. Surabaya: Arkola.

Qaradhawiy, Yusuf. Membedah Islam Ekstrim. Terj: Alwi A.M. Bandung: Mizan (2001).

Robingatun. "Radikalisme Islam dan Ancaman Kebangsaan." Empirisma: Jurnal Pemikiran dan Kebudayaan Islam, Vol. 26, No. 1 (2017).

Shihab, Alwi. Islam Inklusif: Menuju Sikap Terbuka Dalam Beragama. Bandung: Mizan, 1999. 
Sihbudi, Riza. "Membaca Kemungkinan kemerdekaan Negara Palestina." Al-Huda: Jurnal Kajian Ilmu-Ilmu Islam, Vol. 2, No. 5 (2002).

Susanto, Edi. "Kemungkinan Munculnya Paham Islam Radikal Di "Pondok Pesantren"." Tadrîs: Jurnal Pendidikan Islam, Vol. 2, No. 1 (2007). 